\title{
Comparative of Proximate and Mineral Composition of Commercially-Available Millet Types in Katsina Metropolis, Nigeria
}

\author{
Shamsudeen Nassarawa Sanusi ${ }^{1,}$, , Salamatu Ahmad Sulaiman², Hadiza Kabir Bako ${ }^{2}$ \\ Department of Food Science and Technology, Bayero University, Kano, Nigeria \\ Email address \\ shamsudeensunusi2015@gmail.com(S. N. Sanusi) \\ ${ }^{*}$ Corresponding author \\ To cite this article: \\ Shamsudeen Nassarawa Sanusi, Salamatu Ahmad Sulaiman, Hadiza Kabir Bako. Comparative of Proximate and Mineral Composition of \\ Commercially-Available Millet Types in Katsina Metropolis, Nigeria. World Journal of Food Science and Technology. \\ Vol. 3, No. 1, 2019, pp. 14-19. doi: 10.11648/j.wjfst.20190301.13
}

Received: March 8, 2019; Accepted: April 22, 2019; Published: May 23, 2019

\begin{abstract}
The study revealed a high nutritional quality and possible therapeutic effect of the studied millet varieties which are locally sourced and relatively cheaper source of food for a teeming population like ours. The millet varieties were obtained from the central market in Katsina state, Nigeria. The millet varieties (finger millet, pearl millet and fonio millet) were cleaned by washing in water, de-watered, sun dried, milled into flour and stored in sealed polythene bags. The results obtained from the studied millet varieties showed a protein content level within the range of (10.09\%-10.85\%), fat content level between the range $(2.76 \%-4.43 \%)$, carbohydrate, fat and ash content between the range $(71.56 \%-73.18 \%),(2.23 \%-3.24 \%)$ and $(0.86 \%$ $1.94 \%)$ respectively. The mineral composition showed it contained mineral elements of health importance, such as; phosphorus, calcium, potassium, sodium and magnesium as well as other minor elements such as copper, manganese, zinc and iron.
\end{abstract}

Keywords: Finger Millet, Pearl Millet, Fonio Millet, Proximate and Mineral Composition

\section{Introduction}

Millets are important cereals besides wheat, rice, and maize. Millets serve as a major food source for millions of people, especially those who live in hot and humid areas of the world such as Nigeria. They are grown mostly in marginal areas under agricultural conditions in which major cereals fail to give substantial yields [1]. Millets are important foods in many under developed countries because of their ability to grow under adverse weather conditions such as limited rainfall. In contrast, millet is the major source of energy and protein for millions of peoples especially those with low socio-economic status. It has been reported millet has many nutritive and medical functions $[2,3]$. The term millet refers to various group of small seeded cereal crops which are known for their small coarse grains [4]. There are about 6000 varieties of millets grown around the world, the four major types are pearl millet (pennisetum glaucum), which comprises $40 \%$ of the world production, fonio millet (setaria italica) [3], finger millet (Eleusine coracana) and proso millet or white millet (panicum miliceum). Pearl millet produces the largest seeds and it is the variety most commonly used for human consumption [5]. Millet can be referred to as the store-house of nutrition by any nutritional criterion. They are more advanced then rice and wheat [1]. Depending on the species, the proximate composition varies. The Fibre content of millets is higher than that of wheat and rice, with Barnyard millet having fifty times the fiber content of rice [6]. Millet is a rich in B-group vitamin and also in minerals like potassium, phosphorus, iron, copper, magnesium, zinc and manganese [1]. Millets have oil content of $4.2 \%$ of which $50 \%$ is polyunsaturated.

Nigeria as a country is faced with the problem of feeding its teeming population; therefore it is important to explore local biodiversity such as millet which are at present underutilized. In many developing countries such as Nigeria, malnutrition is an endemic dietary problem characterized by protein-energy malnutrition and micro-nutrient deficiency 
[7]. The determination of the nutritional composition of these millet varieties will go a long way in providing information (nutritional data) about the selected millet varieties, which in turn will create awareness about the underlying potentials of this underutilized cereal, hence increasing utilization both industrial and household levels, hereby going a long way in achieving the core objectives of this country in feeding its teeming populace with safe and nutritious food.

Pearl millet (pennisetum glaucum) is also known as spiked millet and bulrush millet [7]. It is certainly the most important and widely grown millet with more than 15,000 lines in the World Germplasm Collection in India [8]. Pearl millet originated in tropical western Africa, where the greatest number of both wild and cultivated genotypes occurs [9]. Depending on the genotype, the plant may grow from 0.5 to $3.5-4 \mathrm{~m}$ and the seeds can be white, light yellow, gray, brown, purple or slate blue in colour $[10,9,7]$. The thousand seed-weight lies between 2.5 to $14 \mathrm{~g}$ with an average weight of $8 \mathrm{~g}[9,7]$. TSW varies from crop to crop and can vary between varieties of the same crop.

Finger millet (Eleusine coracana) represents a staple food for a large segment of the population [9]. It has high nutritional value and is a good source of calcium, phytochemicals and dietary Fibre [7]. As the grains can be stored for long duration without damage from pests and insects, it plays a major role during natural calamities [9]. The height of plants reachehes from 0.4 to $1 \mathrm{~m}$ and the length of the spikes are between $3-13 \mathrm{~cm}[9,7]$. The grains are smaller than those of pearl millet and vary in colour from white to orange-red to deep brown to almost black [9].

Fonio millet (Setaria italic) is also known as Italian, Hungarian, German and Siberian millet [7]. The plant height varies between $1-1.5 \mathrm{~m}$. The inflorescence is tight, has short side branches and varies from $7.5-25 \mathrm{~cm}$ in length and $1.2-$ $5 \mathrm{~cm}$ in diameter $[9,7]$. The panicle resembles the tail of a fox; the colour of the grain varies from yellow to orange to red to brown and black $[9,7]$. The weight of 1000 seeds is about $2 \mathrm{~g}[10]$.

\section{Material and Method}

\subsection{Source of Material}

The millet varieties were obtained from the central markets in Katsina state, Nigeria. All reagents used were of analytical grades and were purchased from a chemical store in Katsina State, Nigeria. The millet varieties (finger millet, pearl millet and fonio) were cleaned by washing in water, de-watered, sun dried, milled into flour and stored in sealed polythene bags [11].

\subsection{Determination of Proximate Composition of Millet Varieties}

The proximate composition of the samples was carried out using the standard procedures of [12].

Moisture content Determination: Moisture content determination was carried out using the air oven (Laboratory oven, Model No: DHG-9101 SA). Petri dishes were washed and dried for minute and cooled in the dessicator for about 20 mins. The petri dishes were weighed $\left(\mathrm{W}_{1}\right)$ and 10 gramme of the sample was added into the dish to give a new weight $\left(\mathrm{W}_{2}\right)$. It was then placed in the oven at $105^{\circ} \mathrm{C}$ for $3 \mathrm{hrs}$, after which it was removed, allowed to cool in the dessicator and oven dried again, this was repeated several times until constant weight was noted $\left(\mathrm{W}_{2}\right)$.

$$
\% \text { Moisture }=\left(W_{2}-W_{3}\right) /\left(W_{2}-W_{1}\right)
$$

Where

$\mathrm{W}_{1}$ = weight of petri dish

$\mathrm{W}_{2}=$ weight of petri dish + sample before drying

$\mathrm{W}_{3}=$ weight of petri dish + sample after drying

Determination of Ash content: Crucible was pre-heated in the oven for $30 \mathrm{mins}$ at $105^{\circ} \mathrm{C}$, cooled in the dessicator for about $1 \mathrm{hr}$ and weighed $\left(\mathrm{W}_{1}\right)$. One gramme of the sample was added into crucible, given a new weight $\left(\mathrm{W}_{2}\right)$

It was then be placed in the muffle furnace for ashing at $55^{\circ} \mathrm{C}$ for $3 \mathrm{hrs}$ until the content became whitish in colour with no black particles, it was removed and cooled in the dessicator, the weight was noted $\left(\mathrm{W}_{3}\right)$.

$\%$ Ash $=\left(W_{2}-W_{3}\right) /\left(W_{2}-W_{1}\right)$

Where

$\mathrm{W}_{1}=$ weight of crucible

$\mathrm{W}_{2}=$ weight of crucible + sample before ashing

$\mathrm{W}_{3}=$ weight of crucible + sample after ashing

Determination of fat content: Filter paper free from fat was weight $\left(\mathrm{W}_{1}\right)$. About 1 gramme of the sample was added into the filter paper, carefully folded and tied to keep the sample intact, the new weight noted $\left(\mathrm{W}_{2}\right)$. A $500 \mathrm{ml}$ round bottom flask was filled up to three-quarter with solvent (n-Hexane). The flask was fitted to soxhlet extraction with a reflux condenser and placed on an electo-mantle heater. Extraction began as the solvent start refluxing several times. Extraction continued for about $6 \mathrm{hrs}$ after which the condenser was detached, the defatted sample removed, and dried to a constant weight in the oven at $105^{\circ} \mathrm{C}$ for $2 \mathrm{hrs}$. The difference between the weight of the defatted sample before and after drying was recorded as the weight of fat $\left(\mathrm{W}_{3}\right)$.

$$
\text { Fat }(\%)=\left(W_{2}-W_{1}\right) / W \times 100
$$

Determination of nitrogen and crude protein

The micro kjeldhal method

About $0.5 \mathrm{~g}$ part of the sample were weighed and transferred into a Kjedahl flask. Using a measuring cylinder, about $5 \mathrm{ml}$ concentrated sulphuric acid and one tablets of kjeldhal catalyst were added to the flask. The flask in an inclined position was gently heated in a fume cupboard, using heating mantle. When the initial vigorous reaction has died down, the heat was increased and digestion was continued until the liquid was clear and free from black or brown colour. The flask was allowed to cool and the mixture was transferred to $100 \mathrm{ml}$ volumetric flask, diluted with distilled water to the mark. About $10 \mathrm{ml}$ of the sample aliquot and $15 \mathrm{ml}$ of $40 \%$ Sodium Hydroxide solution was 
transferred into the distillation apparatus consisting of the flask (500 $\mathrm{ml}$ capacity), stopper carrying a dropping funnel and a splash head adaptor: a vertical condenser. Ten (10) ml of $2 \%$ boric acid solution was measured into a $250 \mathrm{ml}$ conical flask, and a few drops of screened methyl red indicator were added to the flask and then placed on the receiver so that the end of the delivery tube is below the level of the boric acid. A few pieces of granulated zinc and some anti-dumping granules were added to the distillation flask. The apparatus were shaken gently to ensure mixing of the contents. The flask was boiled vigorously until about $25 \mathrm{ml}$ distillate is obtained. The receiver was removed and titrated against a standard acid $0.025 \mathrm{M} \mathrm{H}_{2} \mathrm{SO}_{4}$ till a pink colour end point (TV) is reached.

$$
N(\%)=(0.014 \times T V \times 100 \times 0.025) /(W \times 10) \times 100
$$

Where $\mathrm{W}$ is weight of sample taken.

$$
\% \text { protein }=\mathrm{N} \times \mathrm{F}
$$

Where $\mathrm{F}$ is a factor equal to 5.70 for flour, 6.38 for milk, 5.55 for gelatine and 6.25 for all other food

Determination of crude Fibre: About 5 grams of the sample were weighed $\left(\mathrm{W}_{1}\right)$ and defatted by ether extraction with Soxhlet apparatus and dried. The sample was transfered quantitatively by brushing in a $600 \mathrm{ml}$ beaker of the fibre digestion apparatus. $200 \mathrm{ml}$ of $1.25 \%$ sulphuric acid was added. The beaker were placed on digestion apparatus with pre adjusted heater and boiled for exactly 30 minutes. The beaker was removed and the contents were filtered through California Buchner funnel. The beaker was rinsed with $75 \mathrm{ml}$ of boiling water and washed through the funnel. The washing was repeated 3 times with $50 \mathrm{ml}$ portion of water and then sucks dry. The residue was returned to the beaker by blowing back through the funnel. $200 \mathrm{ml}$ of boiling and $1.25 \%$ sodium hydroxide was added to the beaker and boiled for 30 minutes and the beaker was removed and filtered. The residue was then washed with $25 \mathrm{ml}$ of boiling 1.25 sulphuric acid, followed by three $50 \mathrm{ml}$ portion of water and $25 \mathrm{ml}$ of alcohol respectively. The fibre mat and the residue were then dried at $130 \pm 2{ }^{0} \mathrm{C}$ for 2 hours. It's then cooled in a desiccator and weighed $\left(\mathrm{W}_{2}\right)$.

It was ignited at $600{ }^{0} \mathrm{C} \pm 15$ for 30 minutes. The dishes were removed and cooled in a desiccator and weighed $\left(\mathrm{W}_{3}\right)$. The Fibre was calculated as follows:

(\%) Crude fibre $=\left(W_{2}-W_{3}\right) /\left(W_{1}\right) \times 100$

Where

$\mathrm{W}_{1}=$ weight of sample

$\mathrm{W}_{2}=$ weight of crucible + sample after drying

$\mathrm{W}_{3}=$ weight of crucible + sample after ashing

Determination of carbohydrate: Total carbohydrate was calculated by difference using the following formula:

Carbohydrate $(\%)=100-(\%$ Moisture $+\%$ Ash $+\%$ Fat $+\%$ Protein).

\subsection{Determination of Mineral Composition}

According to method outlined by [5] mineral (manganese, copper, iron, zinc and calcium) content was determined by
Atomic Absorption Spectrophotometry (Model 6800 series Shimazo Corp). The ash obtained from the muffle furnace (product of the ash content determination) was dissolved in $10 \mathrm{ml}$ of $10 \% \mathrm{HCL}$. The mixture was heated on a steam bath to effect complete dissolution and the dissolved ash was filtered into a $100 \mathrm{ml}$ volumetric flask and made up to volume with distilled water. The mineral content was determined using an Atomic Absorption Spectrophotometer (Alpha 4-Chem. Tech Analytical, USA).

\section{Results and Discussion}

\subsection{Proximate Nutrient Composition of Finger Millet (Wet Basis)}

Table 1 shows the proximate composition of finger millet (as determine in this work) as follows; protein $(10.09 \%)$, ash (1.94\%), fibre (3.21\%), fat (3.24), moisture (8.34\%) and carbohydrate $(73.18 \%)$. The protein content was found to be higher than that obtained by [13] but lower than the $14 \%$ obtained by [14]. The Fibre and ash content was found to be lower than the values reported by $[14,15]$ and $[13]$. The fat content was found to be higher than what was reported by [8] but lower than $5.28 \%$ reported by [14]

\subsection{Proximate Nutrient Composition of Pearl Millet (Wet Basis)}

Table 2 shows the proximate composition of pearl millet as determined in this work as follows; protein $(10.41 \%)$, ash $(1.70 \%)$, Fibre $(3.24 \%)$, fat $(4.43 \%)$, moisture $(8.66 \%)$ and carbohydrate (71.56). The protein content was lower than the values obtained by [16], [17] and [18]. The Fibre content was also higher than the values obtained by these researchers while the fat content was higher then the values reported by [18] but lower than the $7.96 \%$ by [16].

\subsection{Proximate Nutrient Composition of Fonio Millet (Wet Basis)}

Table 3 shows the proximate composition of fonio (as determined in this work) as follows; protein $(10.85 \%)$, ash $(0.86 \%)$, Fibre $(2.32 \%)$, fat $(2.76 \%)$, moisture $(10.32 \%)$ and carbohydrate $(72.89 \%)$. The protein content was higher than the values reported by [19], [6] but close to the 10.67 obtained by [4]. The ash content is higher than values obtained by [20] but lower than $3.27 \%$ reported by [21]. The value obtained for the Fibre content is lower than $6.30 \%$ reported by [20], while the fat content obtained is lower than values $(2.83 \%)$ obtained by [21].

\subsection{Mineral Composition of Finger Millet}

The mineral composition of finger millet compared with literature values is shown in Table 1 with the following respective values obtained; magnesium (6.3mg/100), manganese $(2.85 \mathrm{mg} / 100)$, zinc $(0.48 \mathrm{mg} / 100)$, iron $(1.46 \mathrm{mg} / 100)$, copper $\quad(0.06 \mathrm{mg} / 100 \mathrm{~g}), \quad$ sodium $(3.70 \mathrm{mg} / 100 \mathrm{~g})$, calcium $\quad(137.33 \mathrm{mg} / 100)$, potassium 
(35.19mg/100g) and phosphorus (158.43mg/100g). The values obtained suggest that magnesium, phosphorus, potassium and calcium are the bulk of elements in finger millet, this agrees with the report of [22] and [13].

\subsection{Mineral Composition of Pearl Millet}

Table 2. shows the mineral composition of pearl millet (as determined in this work) as follows; magnesium $(4.20 \mathrm{mg} / 100 \mathrm{~g})$, manganese $(0.20 \mathrm{mg} / 100 \mathrm{~g})$, zinc $(0.19 \mathrm{mg} / 100 \mathrm{~g})$, iron $(1.25 \mathrm{mg} / 100 \mathrm{~g})$, copper $(0.09 \mathrm{mg} / 100 \mathrm{~g})$, sodium (5.10mg/100g), calcium (115.54 mg/100g), magnesium, phosphorus, potassium and calcium are the bulk of elements in pearl millet, this agrees with the report of [23] and [24].

\subsection{Mineral Composition of Fonio Millet}

Table 3 shows the mineral composition of fonio as determined in this work as follows; magnesium (2.53 $\mathrm{mg} / 100 \mathrm{~g})$, manganese $(0.03 \mathrm{mg} / 100 \mathrm{~g})$, zinc $(0.45 \mathrm{mg} / 100 \mathrm{~g})$, iron $(0.57 \mathrm{mg} / 100 \mathrm{~g})$, copper $(0.05 \mathrm{mg} / 100 \mathrm{~g})$, sodium $(4.70$ $\mathrm{mg} / 100 \mathrm{~g})$, calcium $(19.70 \mathrm{mg} / 100 \mathrm{~g})$, potassium $(26.53$ $\mathrm{mg} / 100 \mathrm{~g}$ ) and phosphorus (13.42 $\mathrm{mg} / 100 \mathrm{~g})$. The values obtained suggest that magnesium, phosphorus, sodium, potassium and calcium are the bulk of elements in fonio millet, this agrees with the report of [21].

Minerals are important for vital body functions such as acid-base and water balance. The results of mineral analyses of these millet varieties showed that they contain high proportions of major mineral elements such as calcium, phosphorus, magnesium, potassium, sodium [25, 23 and 22] with fair amounts of minor minerals of physiological importance such as copper, manganese, iron and zinc [26, 27 and 25].

Minerals play a vital role in the maintenance of human health. Iron for instance, is an important component of blood and enzymes involved in election transfer. Its deficiency results in fatigue, headache and sore tongue in addition to anemia. Calcium is needed for bone formation while zinc is essential for protein and nucleic acid synthesis, carbohydrate metabolism, successful pregnancy, delivery and normal development [4]. Cereals are rich in minerals but the bioavailability of these minerals is usually low due to the presence of anti-nutritional factors such as phytate and polyphenols [28]. An adequate mineral absorption is important for infants, children, elderly people and people in clinical situation [29]. Millets (Fonio, Finger millet and peal millet) are also rich in minerals but their nutritional quality is dictated by their chemical composition and presence of considerable amounts of anti-nutritional factors that are undesirable. Most of these minerals are essentially required in our diets in minute amounts and their deficiency may result in occurrence of some form of malnutrition or disorders [7].

Table 1. Proximate Nutrient Composition of Finger millet (wet basis).

\begin{tabular}{lllll}
\hline Parameters & & & & \\
\hline Protein (\%) & $10.09 \pm 0.02$ & $14.00 \pm 0.01$ & $10.66 \pm 0.18$ & $5.68 \pm 0.51$ \\
Ash (\%) & $1.94 \pm 0.17$ & $4.22 \pm 0.01$ & $2.84 \pm 0.13$ & $2.21 \pm 0.05$ \\
Fibre (\%) & $3.21 \pm 0.02$ & $3.51 \pm 0.01$ & $3.94 \pm 0.36$ & $4.34 \pm 0.10$ \\
Fat (\%) & $3.24 \pm 0.22$ & $5.28 \pm 0.04$ & $1.42 \pm 0.11$ & $1.68 \pm 0.62$ \\
Moisture (\%) & $8.34 \pm 0.07$ & $10.21 \pm 0.04$ & $7.67 \pm 0.45$ & $11.52 \pm 0.08$ \\
Carbohydrate (\%) & $73.18 \pm 0.03$ & $62.78 \pm 0.01$ & $73.47 \pm 0.01$ & $75.83 \pm 0.02$ \\
Reference & $* * *$ & {$[14]$} & {$[15]$} & {$[13]$} \\
\hline
\end{tabular}

N.B $\mathrm{B}^{* * *}=$ Values as determined in the Laboratory (which are mean values \pm standard deviations of three deteminatios).

Table 2. Proximate Nutrient Composition of pearl millet (wet basis).

\begin{tabular}{lllll}
\hline Parameters & & & & \\
\hline Protein (\%) & $10.09 \pm 0.02$ & $14.00 \pm 0.01$ & $10.66 \pm 0.18$ & $5.68 \pm 0.51$ \\
Ash (\%) & $1.94 \pm 0.17$ & $4.22 \pm 0.01$ & $2.84 \pm 0.13$ & $2.21 \pm 0.05$ \\
Fibre (\%) & $3.21 \pm 0.02$ & $2.83 \pm 0.23$ & 3.17 & $2.40 \pm 0.04$ \\
Fat (\%) & $4.43 \pm 0.08$ & $7.96 \pm 0.58$ & 3.47 & $2.80 \pm 0.05$ \\
Moisture (\%) & $8.66 \pm 0.19$ & $4.96 \pm 0.10$ & 10.34 & $10.70 \pm 0.20$ \\
Carbohydrate (\%) & $71.56 \pm 1.45$ & $66.05 \pm 0.10$ & 81.86 & $70.50 \pm 0.10$ \\
Reference & $* * *$ & {$[16]$} & {$[17]$} & {$[18]$} \\
\hline
\end{tabular}

N.B $* * *=$ values as determined in the laboratory (which are mean values \pm standard deviations of three determinations).

Table 3. Proximate Nutrient Composition of fonio millet (wet basis).

\begin{tabular}{lllll}
\hline Parameters & & & & \\
\hline Protein (\%) & $10.85 \pm 0.26$ & $7.05 \pm 0.07$ & $10.67 \pm 1.10$ & $7.91 \pm 0.11$ \\
Ash (\%) & $0.86 \pm 0.10$ & $3.27 \pm 0.20$ & $0.30 \pm 0.10$ & $2.72 \pm 0.03$ \\
Fibre (\%) & $2.32 \pm 0.16$ & & $6.30 \pm 0.00$ & $0.42 \pm 0.02$ \\
Fat (\%) & $2.76 \pm 0.02$ & $2.83 \pm 0.57$ & $0.11 \pm 0.10$ & $1.22 \pm 0.003$ \\
Moisture (\%) & $10.32 \pm 0.07$ & $11.50 \pm 0.58$ & $11.91 \pm 1.30$ & $12.4 \pm 0.20$ \\
Carbohydrate (\%) & $72.89 \pm 0.21$ & $75.35 \pm 0.20$ & $82.61 \pm 4.60$ & $87.7 \pm 0.10$ \\
Reference & $* * *$ & {$[21]$} & {$[12]$} & {$[19]$} \\
\hline
\end{tabular}

N.B ${ }^{* * *}=$ Values as determined in the Laboratory (which are mean values \pm standard deviations of three deteminatios) 
Table 4. Mineral Composition of Finger millet.

\begin{tabular}{lllll}
\hline Prameter & & & & \\
\hline Magnesium $(\mathrm{mg} / 100 \mathrm{~g})$ & $6.38 \pm 0.02$ & $124.00 \pm 0.08$ & $168.78 \pm 38.44$ & 66.00 \\
Manganese (mg/100g) & $2.85 \pm 0.02$ & & $28.35 \pm 13.70$ & 1.87 \\
Zin $(\mathrm{mg} / 100 \mathrm{~g})$ & $0.48 \pm 0.01$ & $1.95 \pm 0.05$ & $1.80 \pm 0.43$ & 3.84 \\
Iron $(\mathrm{mg} / 100 \mathrm{~g})$ & $1.46 \pm 0.01$ & $2.70 \pm 0.01$ & $26.90 \pm 18.03$ & 0.60 \\
Copper $(\mathrm{mg} / 100 \mathrm{~g})$ & $0.06 \pm 0.01$ & & $0.62 \pm 0.18$ & 281.00 \\
sodium $(\mathrm{mg} / 100 \mathrm{~g})$ & $3.70 \pm 0.10$ & $0.98 \pm 0.04$ & $256.52 \pm 77.85$ & 294.00 \\
Calcium $(\mathrm{mg} / 100 \mathrm{~g})$ & $137.33 \pm 1.53$ & $319.00 \pm 0.01$ & & 280.00 \\
potassium $(\mathrm{mg} / 100 \mathrm{~g})$ & $35.19 \pm 0.42$ & & $121.83 \pm 43.32$ & {$[25]$} \\
phosphorus $(\mathrm{mg} / 100 \mathrm{~g})$ & $158.43 \pm 048$ & $245.00 \pm 0.01$ & {$[22]$} & \\
References & $* * *$ & {$[13]$} & & \\
\hline
\end{tabular}

N.B B $^{* *}=$ Values as determined in the Laboratory (which are mean values \pm standard deviations of three determinations).

Table 5. Mineral Composition of pearl millet.

\begin{tabular}{|c|c|c|c|c|}
\hline \multicolumn{5}{|l|}{ Prameters } \\
\hline Magnesium $(\mathrm{mg} / 100 \mathrm{~g})$ & $4.20 \pm 0.20$ & 97.00 & $177.45 \pm 0.04$ & $93.00 \pm 0.00$ \\
\hline Manganese $(\mathrm{mg} / 100 \mathrm{~g})$ & $0.20 \pm 0.10$ & & & $1.32 \pm 0.00$ \\
\hline Zin $(\mathrm{mg} / 100 \mathrm{~g})$ & $0.19 \pm 0.01$ & & $6.43 \pm 074$ & $1.79 \pm 0.01$ \\
\hline Iron $(\mathrm{mg} / 100 \mathrm{~g})$ & $1.25 \pm 0.01$ & 8.80 & $9.27 \pm 0.24$ & $10.70 \pm 0.09$ \\
\hline Copper (mg/100g) & $0.09 \pm 0.01$ & & & $0.62 \pm 0.00$ \\
\hline sodium (mg/100g) & $5.10 \pm 0.10$ & 9.20 & $112.12 \pm 0.29$ & $16.25 \pm 0.00$ \\
\hline Calcium $(\mathrm{mg} / 100 \mathrm{~g})$ & $24.13 \pm 0.83$ & 42.00 & $50.07 \pm 0.31$ & 52.78 \\
\hline potassium $(\mathrm{mg} / 100 \mathrm{~g})$ & $24.13 \pm 0.83$ & 30.00 & $325.35 \pm 0.23$ & $434.26 \pm 0.00$ \\
\hline phosphorus $(\mathrm{mg} / 100 \mathrm{~g})$ & $121.35 \pm 0.56$ & 360.00 & $399.23 \pm 0.04$ & $1106.77 \pm 1.76$ \\
\hline References & $* * *$ & [23] & [16] & {$[24]$} \\
\hline
\end{tabular}

N.B. ${ }^{* * *}=$ Values as determined in the laboratory (which are mean values \pm standard deviations of three determinations.

Table 6. Mineral composition of Fonio Millet.

\begin{tabular}{lllll}
\hline Prameters & & & & \\
\hline Magnesium $(\mathrm{mg} / 100 \mathrm{~g})$ & $2.53 \pm 0.02$ & 71.00 & 106.00 & 1.21 \\
Manganese $(\mathrm{mg} / 100 \mathrm{~g})$ & $0.03 \pm 0.01$ & & 1.48 & 18.09 \\
Zin $(\mathrm{mg} / 100 \mathrm{~g})$ & $0.45 \pm 0.01$ & 1.67 & 2.30 & 2.12 \\
Iron $(\mathrm{mg} / 100 \mathrm{~g})$ & $0.57 \pm 0.01$ & 3.50 & 4.82 & 1.30 \\
Copper $(\mathrm{mg} / 100 \mathrm{~g})$ & $0.05 \pm 0.01$ & 21.30 & 0.49 & 1.29 \\
sodium $(\mathrm{mg} / 100 \mathrm{~g})$ & $4.70 \pm 0.10$ & 36.50 & 17.20 & 138.33 \\
Calcium $(\mathrm{mg} / 100 \mathrm{~g})$ & $19.70 \pm 0.10$ & 293.30 & 249.00 & 126.50 \\
potassium $(\mathrm{mg} / 100 \mathrm{~g})$ & $26.53 \pm 0.57$ & & 237.00 & {$[30]$} \\
sphosphorus $(\mathrm{mg} / 100 \mathrm{~g})$ & $13.42 \pm 0.26$ & {$[21]$} & {$[26]$} & \\
References & $* * *$ & & \\
\hline
\end{tabular}

N.B. $* * *=$ Values as determined in the laboratory (which are mean values \pm standard deviations of three determinations.

\section{Conclusion}

The results obtained from this work showed that the selected millet varieties (finger millet, pearl millet and fonio) are all good sources of essential nutrients which could make substantial contribution to the intakes of some minerals. Consequently, these selected millet varieties when properly utilized through effective products development programs, have the potential of helping in overcoming malnutrition and hunger among the vulnerable groups in Nigeria.

\section{References}

[1] Adekunle, A. A. (2012). Agriculture innovation in sub-sahara Africa: experiences from multiple stake holder approaches. Forum for Agricultural Research in African, Ghana. ISBN 978-99881-2-4

[2] Obilana, A. B. and Manyan, E. (2002). Millets. In:
Pseudocereals and less common cereals: Grain properties and utilization potential (edited by BELTON, P. and TAYLOR, J.). Pp. 177-218. New York: Springer.

[3] Yang, X. Z., Wan, L., Perry H., Lu, Q., Wang, C., Hao, J., Li, F., Xie, J., Yu, T., Cui, T., Wang, M., Li and Ge, Q. H. (2012). Early millet use in northan china. Proc. Nat. Acad. Science. USA Pp.1-5.

[4] Weber, S. A. and Fuller, D. Q. (2006). Millets and their role in early agriculture. Paper presented in the International Seminar 'First Farmers in Global perspective, Lucknow, India, January 18-20, Pp-69-90.

[5] Mariac, C., Luong, I., Kapran, A., Mamadous, F., Sagnard M., Deu, J., Chantereau, B., Gerard, J., Ndjeunga, G., Bezanco, j., pham, V and Vigourous, Y. (2006). Diversity of wild and cultivated pearl millet accessions (pennisetum glaucum [L.] R. $\mathrm{Br}$.) in Niger assessed by microsatellite markers. Theor. Appl. Genet. 114: 49-58.

[6] World Health Organization (2006). Global prevalence of vitamin A deficiency. WHO/NUT/95.3. Geneva. Pg 49. 
[7] Bavec, F and Bavec, M. (2002). Millets in Organic production and Use of Alternative Crops, CRC Press, London, NY, chapter 4 .

[8] McDonough C. M., Rooney L. W and Serna-Saldivar S. O. (2000). The Millets in Handbook of Cereal Science and Technology, Second Edition, Revised and Expanded, Kurl K. and Ponte J. G., Jr. (eds)., Marcel Dekker Inc., NY, Chapter 4. s

[9] FAO (1995). Sorghum and millets in human nutrition Pp. 132. Rome, United Nations Food and Agriculture Organisation.

[10] Hulse J. H., Laining E. M. and Pearson O. E. (1980). Sorghum and the Millets: Their Composition and Nutritive Value, Academic Press, London NY, Chapters 1, 24 and 5.

[11] Echendu, C. A., Obizobz, I. C., Anyika, J. U., and Ojimelukwe, P. C. (2009). Changes in Chemical Composition of treated and untrated hungry rice " Acha" (Digitaria exilis). Pakistan journal of nutrition, 8 (11): 1779-1785.

[12] AOAC (2005). Official methods of analyses. Washington, DC, Association of Official Analytical Chemists.

[13] Fasasi, O. S. (2009). Proximate, antinutritional factors and functional properties of processed pearl millet (pennisetum glaucum). Journal of food technology, 7 (3): 92-97.

[14] Rotimi, T. F. (2011). The effect of processing on the nutritional value of finger millet (Elusine coracona) seed. A master thesis of the department of Biochemistry, Ahmadu Bello University, Zaria Nigeria.

[15] Banusha, S. and Vasantharuba, S. (2013). Effect of malting on nutritional contents of finger millet and Mung bean. American Eurasian journal of agricultural and environmental science 13 (12): 164-1646.

[16] Kunyanga, C. N., Imungi, J. K., and Vellingiri, V. (2013). Nutritional evaluation of indigenous foods with potential food-based solution to alleviate hunger and malnutrition in kenya. Journal of applied bioscience 67: 5277-5288.

[17] Akereddolu, I. A., Addo, A. A and Akeredolu, O. A. (2005) Clinical evaluation of pearl millet conophour weaning mix as supplementary food for Nigerian children. Brazilian archives of biology and technology volume 48 (4): 531-536.

[18] Mariac, C., Luong, I., Kapran, A., Mamadous, F., Sagnard M., Deu, J., Chantereau, B., Gerard, J., Ndjeunga, G., Bezanco, j., pham, V and Vigourous, Y. (2006). Diversity of wild and cultivated pearl millet accessions (pennisetum glaucum [L.] R. $\mathrm{Br}$.) in Niger assessed by microsatellite markers. Theor. Appl. Genet. 114: 49-58.

[19] McDonough C. M., Rooney L. W and Serna-Saldivar S. O. (2000). The Millets in Handbook of Cereal Science and
Technology, Second Edition, Revised and Expanded, Kurl K. and Ponte J. G., Jr. (eds)., Marcel Dekker Inc., NY, Chapter 4. s

[20] Ayo, J. A., Ayo, V. A., Nkama, I. and Adewori, R. (2007). Physiochemical, in-vitro digestibility and organoleptic evaluation of "Acha" wheat biscuit supplemented with soybean flour. Nigerian food journal 25 (1): 77-89.

[21] Anounye, J. C., Onuh, J. O., Egwim, E. and Adeyemo, S. O. (2010). Nutrient and anti-nutrient composition of extruded acha/soybean blends. Journal of food processing and preservation, 34: 680-691.

[22] Shimelis, A., Mulugeta, T. and Dawit, A. (2009). Chemical composition of local and improved finger millet (Eleusive coracona (L) gaertin) varieties grown in Ethiopia. Ethiopia journal of heath science, 19 (1): 1-8.

[23] Fasasi, O. S. (2009). Proximate, antinutritional factors and functional properties of processed pearl millet (pennisetum glaucum). Journal of food technology, 7 (3): 92-97.

[24] Abdelrahman, S. M., Elmaki, H. B., Idris, W. H., Babiker, E. E., and El Tinay, A. H. (2005). Antinutritional factors content and minerals availability of pearl millet (pennisetum glaucum) as influenced by domestic processing methods and cultivar. Journal of food Technoogy, 3 (5): 397-403.

[25] Shashi, B. K., Sharan S., Hittalamani, S. Shankar, A. G., and Nagarathna (2007). Micro-nutrients composition, antinutritional factors and bioaccessibility of iron in different finger millet (Elusine coracona) genotypes. Karanataka journal of agricultural science 20 (3): 583-585.

[26] Glew, R. H., Laqbes, E. P., Presley, J. M., Schulze, J., Andrews, R., Wang, Y., Chang, Y., and Chuang, L. (2013). Fatty acid, amino acid, mineral and antioxidant content of Acha (Digitaria exilis) grown on the Jos plateau, Nigeria. International journal of nutrition and metabolism, 5 (1): 1-8

[27] Echendu, C. A., Obizobz, I. C., Anyika, J. U., and Ojimelukwe, P. C. (2009). Changes in Chemical Composition of treated and untrated hungry rice " Acha" (Digitaria exilis). Pakistan journal of nutrition, 8 (11): 1779-1785.

[28] Verdeal, K. and Lorenz, K. (1977). Alkylresorcinals in wheat, rye and triticale. Cereal Chemistry, 54, 475-483.

[29] Badi, S. M., Hoseney, R. C. and Casady, A. J. (1976). Pearl millet. I. Characterization by sem, amino acid analysis, lipid composition and prolamine solubiliy. Cereal Chemistry, 53, 478-487.

[30] Belton P. S and John R. N. (2002). Grain properties and utilization potential of Pseudocereals and less common cereals. Springer-verlag Berlin Heidelberg publisher page 201. 